\title{
ANALISIS KANDUNGAN ZAT PEMUTIH "KLORIN" PADA IKAN ASIN DI PASAR TRADISIONAL (PABEAN) SURABAYA TAHUN 2015
}

\author{
Novi Alita Anuradha, AT. Diana Nerawati, Erna Triastuti
}

\begin{abstract}
Salted fish which uses Non Food Additives are often found in the community. Chlorine bleach material is feared to be added to the salted fish sold in traditional markets. Chlorine is an important chemical in water purification, disinfectant, bleach, and mustard gas.

This is a descriptive research with the objective of determining the chlorine contained in some kinds of salted fish sold in "Surabaya PabeanMarket" by conducting laboratory tests and physical quality assessment, as well as sellers level of knowledge about food bleaching agents. The result indicated that 23 samples contained chlorine and 7 samples of salted fish dis not contain chlorine.Quantitative laboratory test on salted fish samples showedthat out of 30 samples, all positive contained chlorine $(100 \%)$ with the highest level in medananchovies type of $9.335 \mathrm{ppm}$ and the lowest was on the type of Gulama salted fish at 0.0103 (requirement of 0,00 or negative) that was banned to added to food by Permenkes 033 of 2012 on Food Additives. Measurement ontraders' level of knowledge on the production of salted fish shows that 9 out of 15 sellerspossessed a good level of knowledge about the food bleach substance.

To prevent salted fish containing chlorine, Department of Healthand other health institutions are suggested to conduct education to traders on the dangers of chlorine used in food by the that they do not use chlorine as a bleaching agent.
\end{abstract}

\section{Keywords: Chlorine, Salted Fish, and Bleach}

\section{PENDAHULUAN}

Pangan merupakan kebutuhan dasar manusia yang paling utama. Fungsi dari makanan adalah salah satunya sebagai sumber energi. Ada tiga komponen penting dalam pembentukan energi yang sangat di butuhkan bagi setiap manusia yaitu karbohidrat, lemak, dan protein (Hany Rahman,2013). Ikan asin merupakan salah satu sumber protein hewani, kandungan protein pada ikan terbilang cukup tinggi. Ikan asin tidak hanya digemari oleh masyarakat kelas bawah, tetapi juga golongan masyarakat kelas menengah bahkan kelas atas dan sangat populer dikalangan masyarakat Indonesia (Eva Waty Agung,2007). Maka, dalam proses pembuatan ikan asin harus memenuhi persyaratan keamanan pangan di Indonesia.

Menurut Badan Pengawas Obat dan Makanan (BPOM) tahun 2015, ikan asin termasuk ke dalam bahan pangan yang kerap ditambah bahan-bahan yang bukan Bahan Tambahan Pangan (Banjarmasin Tribunnews,2015). Berdasarkan Peraturan Menteri Kesehatan No. 033 tahun 2012 tentang BTP, klorin tidak tercatat sebagai bahan tambahan makanan dalam perlakuan tepung. Sedangkan yang termasuk BTP dalam perlakuan tepung adalah L-Amonium laktat, Amonium klorida, Kalsium sulfat,
Natrium Stearoil-2 laktilat, dan Kalsium oksida.

Klorin, baik dalam bentuk gas maupun cairan mampu mengakibatkan iritasi berupa gatalgatal pada mulut, tenggorokan, esofagus, dan lambung dengan pendarahan, perforasi (perlubangan), dan pada akhirnya kematian Klorin berasal dari bahasa Yunani khloros yang berarti hijau. Pada umumnya masyarakat mengenal senyawa ini sebagai kaporit. Klorin merupakan bahan kimia penting dalam pemurnian air dan desinfektan (Dian Novita Sinuhaji,2009). Meskipun berbahaya klorin sering digunakan sebagai bahan tambahan pangan. Hal ini juga didukung dari observasi yang dilakukan oleh penulis. Dari tiga sampel ikan asin yang diperiksa pada Laboratorium Poltekkes Kemenkes Surabaya Tahun 2015 menunjukkan bahwa seluruhnya positif mengandung klorin dengan kadar 6,361 ppm (Ikan asin teri medan dari Pasar Pabean) ,3,288 ppm (ikan asin kelotok dari Pasar Pucang) dan 7,072 ppm (ikan asin dodok dari Pasar Tambahrejo).

Data PD Pasar Surya Surabaya menyatakan bahwa pasar Pabean adalah pasar ikan terbesar dan terlengkap di Surabaya karena Pasar Pabean menyediakan barang-barang yang lengkap, pengunjung pun boleh 
menawar dan juga membeli dalam jumlah kecil atau mengecer (PD Pasar Surya,2013). Dengan didasarkan atas pertimbangan serta fakta-fakta, maka penelitian ini bertuujuan untuk mengetahui adanya kandungan zat pemutih "Klorin" pada ikan asin di Pasar Tradisional (Pabean) Surabaya tahun 2015

\section{METODE PENELITIAN}

Penelitian ini termasuk jenis penelitian yang bersifat deskriptif yang bertujuan untuk menggambarkan secara jelas dan tepat suatu fenomena sifat, keadaan, gejala, suatu individu atau kelompok tertentu.

Dalam penelitian ini yang menjadi populasi adalah seluruh ikan asin dan pedagang di Pasar Pabean Kota Surabaya, dengan jumlah 30 pedagang. Sampel yang diambil untuk tingkat pengetahuan adalah 15 pedagang dan untuk sampel ikan asin adalah sebanyak 30 sampel yang terdiri dari 6 jenis ikan dari 5 daerah yang berbeda.

Teknik pengambilan sampel yang dilakukan dengan menggunakan Purposive Sampling yaitu pemilihan sampel dengan menggunakan kriteria yang ditentukan oleh penulis.

HASIL PENELITIAN DAN PEMBAHASAN A. Pedagang Ikan Asin di Psar Pabean Surabaya

Hasil penelitian terhadap 15 pedagang diketahui bahwa sebagian besar (47\%) tingkat pendidikan responden adalah tamat SD. Rendahnya pendidikan akan mempengaruhi tingkat pengetahuan seseorang, seperti pedagang yang menjual ikan asin yang memakai klorin, apabila tingkat pengetahuan rendah maka akan mempengaruhi perilaku pedagang dalam hal pemilihan ikan asin yang akan dijual kepada masyarakat.Sebagian besar pedagang ikan di Pasar Pabean Surabaya mempunyai jenis Kelamin perempuan dengan prosentase 71 $\%$ (11 pedagang). Pedagang perempuan cenderung lebih teliti dalam memilih ikan asin yang akan dijual masyarakat, sedangkan pedagang laki-laki berpikir bahwa mereka menjual ikan asin hanya untuk mendapatkan uang serta dapat mencukupi kebutuhan sehari-hari_keluarga.

\section{B. Hasil Penilaian Kondisi Fisik dan Kandungan Klorin Pada Ikan Asin}

Tabel 1.

Hasil Penilaian Kondisi Fisik Ikan Asin, Kandungan Klorin Dengan Tingkat Pengetahuan Pedagang Ikan Asin Di Pasar Pabean Surabaya Tahun 2015

\begin{tabular}{|c|c|c|c|c|c|}
\hline No & \multicolumn{2}{|c|}{ Pedagang } & $\begin{array}{c}\text { Tk. } \\
\text { Pengetahuan }\end{array}$ & $\begin{array}{c}\text { Kual. } \\
\text { Fisik Ikan Asin }\end{array}$ & $\begin{array}{c}\text { Klorin } \\
(+/-)\end{array}$ \\
\hline 1 & \multicolumn{2}{|c|}{2} & 3 & 4 & 5 \\
\hline \multirow{6}{*}{1} & \multirow{6}{*}{ SDA } & K1 & \multirow{6}{*}{ Baik } & Berpemutih & + \\
\hline & & $\mathrm{K} 2$ & & Berpemutih & + \\
\hline & & K3 & & $\begin{array}{c}\text { Tidak } \\
\text { Berpemutih }\end{array}$ & + \\
\hline & & $\mathrm{K} 4$ & & Berpemutih & + \\
\hline & & K5 & & $\begin{array}{c}\text { Tidak } \\
\text { Berpemutih }\end{array}$ & + \\
\hline & & K6 & & $\begin{array}{c}\text { Tidak } \\
\text { Berpemutih }\end{array}$ & + \\
\hline \multirow{6}{*}{2} & \multirow{6}{*}{ LA } & S1 & \multirow{6}{*}{ Kurang Baik } & Berpemutih & + \\
\hline & & S2 & & Berpemutih & + \\
\hline & & S3 & & Berpemutih & + \\
\hline & & S4 & & Berpemutih & + \\
\hline & & S5 & & Berpemutih & + \\
\hline & & S6 & & Berpemutih & + \\
\hline \multirow{6}{*}{3.} & \multirow{6}{*}{ GR } & W1 & \multirow{6}{*}{ Baik } & Berpemutih & + \\
\hline & & W2 & & Berpemutih & + \\
\hline & & W3 & & $\begin{array}{c}\text { Tidak } \\
\text { Berpemutih }\end{array}$ & + \\
\hline & & W4 & & Berpemutih & + \\
\hline & & W5 & & Berpemutih & + \\
\hline & & W6 & & $\begin{array}{c}\text { Tidak } \\
\text { Berpemutih }\end{array}$ & + \\
\hline
\end{tabular}




\begin{tabular}{|c|c|c|c|c|c|}
\hline \multirow{6}{*}{4.} & \multirow{6}{*}{ MDR } & M1 & \multirow{6}{*}{ Kurang Baik } & Berpemutih & + \\
\hline & & M2 & & Berpemutih & + \\
\hline & & M3 & & Berpemutih & + \\
\hline & & M4 & & Berpemutih & + \\
\hline & & M5 & & Berpemutih & + \\
\hline & & M6 & & Berpemutih & + \\
\hline \multirow{6}{*}{5.} & \multirow{6}{*}{ MJK } & N1 & \multirow{6}{*}{ Baik } & Berpemutih & + \\
\hline & & N2 & & $\begin{array}{c}\text { Tidak } \\
\text { Berpemutih }\end{array}$ & + \\
\hline & & N3 & & $\begin{array}{c}\text { Tidak } \\
\text { Berpemutih }\end{array}$ & + \\
\hline & & N4 & & Berpemutih & + \\
\hline & & N5 & & Berpemutih & + \\
\hline & & N6 & & Berpemutih & + \\
\hline
\end{tabular}

Sumber : Hasil Pemeriksaan Lab. Terpadu Poltekkes Kemenkes Surabaya

Berdasarkan hasil observasi secara fisik pada sampel ikan asin yang dijual di Pasar Pabean Surabaya didapatkan hasil bahwa sebanyak $23(76,67 \%)$ sampel ikan asin mempunyai ciri-ciri ikan asin berpemutih dan sisanya (23,33\%) tidak mempunyai ciri-ciri ikan asin berpemutih. Ikan asin yang tidak memperlihatkan mempunyai ciri-ciri berpemutih dapat disebabkan karena jumlah zat pemutih yang tidak terlalu besar, warna dan tekstur asli dari ikan asin. Ciri-ciri ikan asin yang mengandung klorin adalah warna putih mencolok, tidak dihinggapi lalat, tidak berbau ikan asin, warna akan luntur jika dicuci dengan air hangat, tekstur ikan asin akan lembek jika dicuci dengan air hangat. Hasil Identifikasi zat pemutih klorin pada ikan asin di pasar pabean Surabaya terhadap 30 sampel ikan asin yang ditunjukkan pada tabel 1 , dapat diketahui bahwa semua ikan asin positif menggunkan zat pemutih klorin. Hal ini tidak sesuai dengan Peramenkes No. 033 tahun 2012 tentang Bahan Tambahan Pangan. Kejadian seperti ini perlu diwaspadai karena zat pemutih klorin merupakan zat pemutih yang digunakan pada perusahaan air bersih yang dapat mengakibatkan kematian apabila terakumulasi dalam jumlah yang cukup besar dan waktu yang cukup lama. Jika sejumlah kecil dari pemutih (3-6\% hipoklorit) tertelan (ingesti), efeknya iritasi pada sistem gastrointestinal. Jika konsentrasi pemutih yang tertelan lebih besar (10\% hipoklorit ) atau lebih, efek yang dirasakan adalah iritasi korosif hebat pada mulut, tenggorokan, esofagus, dan lambung dengan pendarahan, perforasi (perlubangan), dan pada akhirnya kematian (Murdiyanto,2012). 


\section{Tingkat Pengetahuan Pedagang tentang Zat Pemutih Klorin Pada Ikan Asin di Pasar Pabean Surabaya}

Tabel 2.

Hasil Penilaian Tingkat Pengetahuan Pedagang

Ikan Asin Yang Dijual Di Pasar Pabean SurabayaTahun 2015

\begin{tabular}{|c|c|c|c|c|c|c|c|c|c|c|c|c|c|c|c|c|c|}
\hline \multirow{2}{*}{ No } & \multirow{2}{*}{$\begin{array}{c}\text { Komponen } \\
\text { Penilaian }\end{array}$} & \multicolumn{15}{|c|}{ Responden } & \multirow{2}{*}{$\begin{array}{l}\text { Total } \\
\text { Skore }\end{array}$} \\
\hline & & $\mathbf{K}$ & D & BB & $\mathbf{S}$ & $\mathbf{R}$ & $\mathbf{U}$ & $\mathbf{w}$ & I & $\mathbf{T}$ & $M$ & $\mathbf{G}$ & $\mathbf{v}$ & $\mathbf{N}$ & A & DD & \\
\hline 1 & 2 & \multicolumn{3}{|c|}{3} & \multicolumn{3}{|c|}{4} & \multicolumn{3}{|c|}{5} & \multicolumn{3}{|c|}{6} & \multicolumn{3}{|c|}{7} & 8 \\
\hline 1 & $\begin{array}{l}\text { Bahan pemutih } \\
\text { adalah bahan yang } \\
\text { mampu membuat } \\
\text { tampilan ikan menjadi } \\
\text { lebih lebih putih } \\
\text { sehingga makanan } \\
\text { akan menjadi lebih } \\
\text { menarik. }\end{array}$ & 1 & 1 & 1 & 1 & 0 & 1 & 1 & 1 & 1 & 1 & 0 & 1 & 1 & 1 & 0 & $\begin{array}{c}12 \\
(80 \%)\end{array}$ \\
\hline 2 & $\begin{array}{l}\text { Titanium Dioksida } \\
\text { merupakan salah satu } \\
\text { bahan pemutih } \\
\text { makanan yang } \\
\text { diperbolehkan }\end{array}$ & 1 & 0 & 1 & 0 & 1 & 0 & 0 & 1 & 1 & 0 & 1 & 0 & 0 & 1 & 0 & $\begin{array}{c}7 \\
(47 \%)\end{array}$ \\
\hline 3 & $\begin{array}{l}\text { Bahan pemutih yang } \\
\text { tidak boleh digunakan } \\
\text { dalam makanan } \\
\text { adalah klorin (kaporit) }\end{array}$ & 0 & 1 & 1 & 1 & 1 & 1 & 1 & 1 & 0 & 1 & 1 & 0 & 1 & 1 & 0 & $\begin{array}{c}11 \\
(73 \%)\end{array}$ \\
\hline 4 & $\begin{array}{l}\text { Klorin (Kaporit) } \\
\text { merupakan zat yang } \\
\text { berbahaya bagi tubuh } \\
\text { manusia bila masuk } \\
\text { ke dalam tubuh } \\
\text { manusia }\end{array}$ & 0 & 1 & 1 & 1 & 0 & 0 & 0 & 0 & 0 & 0 & 1 & 1 & 0 & 1 & 0 & $\begin{array}{c}6 \\
(40 \%)\end{array}$ \\
\hline 5 & $\begin{array}{l}\text { Ciri-ciri ikan asin yang } \\
\text { mengandung zat } \\
\text { pemutih adalah } \\
\text { warna ikan asin akan } \\
\text { luntur jika direndam } \\
\text { dengan air hangat }\end{array}$ & 1 & 1 & 0 & 0 & 1 & 0 & 1 & 1 & 1 & 0 & 1 & 0 & 0 & 0 & 0 & $\begin{array}{c}7 \\
(47 \%)\end{array}$ \\
\hline 6 & $\begin{array}{l}\text { Klorin (Kaporit) } \\
\text { digunakan untuk } \\
\text { menjernihkan air }\end{array}$ & 1 & 1 & 1 & 0 & 1 & 1 & 1 & 1 & 0 & 0 & 1 & 1 & 1 & 1 & 1 & $\begin{array}{c}12 \\
(80 \%)\end{array}$ \\
\hline & Skore & 4 & 5 & 5 & 2 & 4 & 3 & 4 & 4 & 3 & 2 & 5 & 3 & 3 & 3 & 1 & 55 \\
\hline & asifikasi Penilaian & B & B & B & $\begin{array}{l}K \\
B\end{array}$ & B & $\begin{array}{l}K \\
B\end{array}$ & B & $\begin{array}{l}\mathrm{K} \\
\mathrm{B}\end{array}$ & $\begin{array}{l}K \\
B\end{array}$ & $\begin{array}{l}\mathrm{K} \\
\mathrm{B} \\
\end{array}$ & B & $\begin{array}{l}\mathrm{K} \\
\mathrm{B}\end{array}$ & $\begin{array}{l}\mathrm{K} \\
\mathrm{B}\end{array}$ & $\begin{array}{l}\mathrm{K} \\
\mathrm{B}\end{array}$ & $\begin{array}{l}\mathrm{K} \\
\mathrm{B}\end{array}$ & \\
\hline
\end{tabular}

Sumber : Data Primer 2015

$\begin{array}{lrrr}\text { Pabean Surabaya } & (60 \%) & 9 & \text { pedagang } \\ \text { termasuk } & \text { dalam } & \text { kategori } & \text { tingkat }\end{array}$ pengetahuan kurang baik, sedangkan sisanya (40\%) termasuk dalam kategori tingkat pengetahuan yang sudah baik. Pedagang yang tidak mengetahui bahan pemutih yang diperbolehkan dan dilarang dapat disebabkan karena kurangnya sosialisasi atau penyuluhan yang dilaukan oleh BBPOM tentang bahan pemutih pangan yang diperbolehkan dan bahayanya jika mengkonsumsi pangan yang mengandung bahan pemutih yang dilarang. Akibatnya, pedagang atau produsen akan menggunakan segala bahan pemutih baik yang diperbolehkan ataupun yang tidak diperbolehkan.

Pedagang yang tidak mengetahui efek yang terjadi jika klorin masuk ke dalam tubuh manusia dan fungsi dari klorin yang sesungguhnya dapat menyebabkan pedagang menganggap bahwa klorin tidak berbahaya jika masuk ke dalam tubuh manusia karena zat pemutih klorin sudah sering digunakan dalam kehidupan seharihari.

\section{KESIMPULAN}

1. Kondisi Fisik Ikan Asin yang dijual di Pasar Pabean Surabaya diperoleh hasil bahwa sebanyak $23(76,67 \%)$ sampel ikan asin mempunyai ciri-ciri berpemutih.

2. 30 sampel ikan asin di pasar Pabean Surabaya positif mengandung bahan pemutih klorin dengan kadar tertinggi terdapat pada ikan asin teri medan dari Mojokerto sebesar 9,335 ppm dan kadar terendah terdapat pada ikan asin Gulama dari Gresik sebesar 0,0103 ppm

3. Tingkat pengetahuan 15 pedagang ikan asin tentang klorin (Kaporit) adalah 9 
pedagang (60\%) termasuk dalam kategori tingkat pengetahuan kurang baik, dan 6 pedagang (40\%) termasuk dalam kategori tingkat pengetahuan yang sudah baik.

\section{Saran}

Sebaiknya BBPOM atau instansi kesehatan lainnya perlu mengadakan sidak pengawasan terhadap ikan asin yang dijual oleh pedagang di wilayah pasar tradisional agar melacarkan program Keamanan Pangan pada Bahan Pangan yang dijual di pasar tradisional. Serta dapat dilakukan penyuluhan tentang bahaya penggunaan klorin kepada pedagang yang ada di lingkungan pasar.

\section{DAFTAR PUSTAKA}

Agung, Eva Wati, 2007. Lauk Ikan Asin.Jakarta.Gramedia Pustaka Utama

Alamsyah, Yuyun,2011.Antisipasi Krisis Global Bisnis Fast Food. Jakarta, Elex Media Komputindo : 106.

Alsuhendra dan Ridawati. 2013. Bahan Toksik Dalam Makanan. Bandung: PT. Remaja Rosdakarya

Departemen Kesehatan Republik Indonesia, 2012. Peraturan Menteri Kesehatan RI Nomor 033 Tahun 2012 tentang Bahan Tambahan Pangan.

Eka, Resya.2013.Rahasia Mengetahui Makanan Berbahaya.Cibubur:Titik Media.

Herniati, DwiRatna. 2010. NikmatDenganMakananSehatdanBer gizi, CV Ricardo: Jakarta.

Indrawati, AnakAgungAyuDiah, 2011. Perlindungan Hukum Konsumen Dalam Pelabelan Produk Pangan

Irianto, Koes,2013. Pencegahan dan Penanggulangan Keracunan Bahan Kimia Berbahaya.Bandung:Yrama Widya :7-126

Suyanti,2010. Panduan Mengolah 20 Jenis Buah.Depok:Penebar Swadaya:37
Institut Pertaian Bogor,2006.Ikan Asin.Bogor,Jurusan Tekonologi Pangan dan Gizi-IPB:93dari http://www.warintek.ristek.go.id/pa ngan_kesehatan/pangan/ipb/Ikan\% 20asin.pdf. Diakses pada tanggal 17 Januri 2015 pukul 12.10 wib.

Malano,Herman,2011. Selamatkan Pasar Tradisional.Jakarta, Gramedia Pustaka Utama: 18

Mukono.2010.Toksikologi Lingkungan.Surabaya.Airlangga University Press.

Nasution, Suryasih Mustika,2013.Analisa Kandungan Klorin $\left(\mathrm{Cl}_{2}\right)$ Pada Beberapa Merek Pembalut Wanita Yang Beredar di Pusat Perbelanjaan Di Kota Medan, Jurusan Kesehatan Masyarakat, FKM-USU:9-13

Notoatmojo Soekidjo. 2012. MetodologiPenelitianKesehatan. Jakarta :RinekaCipta.

Rahman, Trisandy Kartini, 2014. Analisa Kadar Formalin Pada Ikan Asin Yang Dipasarkan.Gorontalo:Universitas Gorontalo: 5-14

Saprianto, Cahyo dan Diana Hidayat,2006. Bahan Tambahan Pangan.Yogyakarta:Kanisius: 6

Seto, Sagung,2001.Pangan dan Gizi IImu, Teknologi, Industri, dan Perdagangan.Bogor,Jurusan Teknologi Pangan dan Gizi-IPB:1

Subroto, Muhammad,2008. Real Food True Health.Jakarta Selatan:Agromedia:9

Suparlan,2012. Pengantar Pengawasan Hygiene Sanitasi Tempat-tempat Umum, Wisata dan Usaha-Usaha Untuk Umum.Surabaya:Percetakan DuaTujuh : 91

Tim Dapur Demedia,2011. Lauk Sedap Dari Ikan Asin Untuk Sehari Hari.Jakarta Selatan:Demedia Pustaka: 6

Widoyoko, Eko Putro,2012.Teknik Penyusunan Instrumen Penelitian.Yogyakarta:Pustaka Pelajar:116 